\title{
A new species of Mymarothecium and new host and geographical records for $M$. viatorum (Monogenea: Dactylogyridae), parasites of freshwater fishes in Brazil
}

\author{
Simone Chinicz Cohen ${ }^{1}$ and Anna Kohn ${ }^{1,2}$ \\ ${ }^{1}$ Laboratório de Helmintos Parasitos de Peixes, Departamento de Helmintologia, Instituto Oswaldo Cruz, FIOCRUZ, Av. Brasil \\ 4365, 21040-900, Rio de Janeiro, RJ, Brasil; \\ ${ }^{2}$ Research fellow of Conselho Nacional de Desenvolvimento Científico e Tecnológico - CNPq
}

Key words: Monogenea, Mymarothecium boegeri, Mymarothecium viatorum, freshwater fishes, Colossoma macropomum, Piaractus brachypomus, Piaractus mesopotamicus, Brazil

\begin{abstract}
Mymarothecium boegeri sp. n. (Monogenea: Dactylogyridae) is described from the gills of Colossoma macropomum Cuvier (Characidae), collected from the aquaria of the "Centro de Pesquisas em Aquicultura, Departamento Nacional de Obras Contra as Secas (DNOCS)", Pentecoste City, State of Ceará, Brazil. Mymarothecium viatorum Boeger, Piasecki et Sobecka, 2002 is reported from the type host, Piaractus brachypomus (Cuvier) (Characidae) and from a new host, P. mesopotamicus (Holmberg) (Characidae), confirming the occurrence of M. viatorum in the Neotropical Region. The new species differs from the congeneric species in the structure of male copulatory complex; it is more closely related to M. viatorum by the presence of a posteromedial projection on ventral bar.
\end{abstract}

Expeditions to the "Departamento Nacional de Obras Contra as Secas (DNOCS)", Pentecoste City, State of Ceará, Brazil, were carried out to study the helminth fauna of fishes from the dam and aquaria of the Centro de Pesquisas em Aquicultura Rodolfo von Ihering.

Mymarothecium was proposed by Kritsky et al. (1996) for parasites characterized by having an anteromedial process on the ventral bar; a non-sclerotized vagina, opening on the middorsal, dextrodorsal or dextroventral surfaces and a non-coiled copulatory complex; the genus was erected with four new species, $M$. dactylotum, M. galeolum, M. perplanum, and M. whittingtoni. Recently, Boeger et al. (2002) described $M$. viatorum from Piaractus brachypomus in a warm-water canal of the Pomorzany power plant in Poland, bearing a posteromedial process on the ventral bar.

In the present study, $M$. viatorum is reported from the type host and from a new host, $P$. mesopotamicus, confirming the occurrence of this parasite species in South America on the type host and on a relative in the Neotropical Region.

A new species of Mymarothecium is herein described from the gills of Colossoma macropomum.

\section{MATERIALS AND METHODS}

Fishes were obtained from the aquaria of the research centre in aquiculture "Rodolfo von Ihering, DNOCS", Pentecoste City, State of Ceará, Brazil. The gills were removed and placed in bowls containing 1:4,000 formalin and agitated. After 1 hour formaldehyde was added to obtain a $4 \%$ solution. In the laboratory, the parasites were collected with the aid of a stereoscopic microscopic, fixed and stored in 4\% formalin. Some specimens were mounted unstained in Hoyer's medium for study of the sclerotized parts and others were stained with Gomori's trichrome and mounted in Canada balsam. All measurements are in micrometres; the range is followed by the mean in parentheses and the number of specimens measured when more than two. Numbering of hook pairs follows Mizelle (1936). Holotype and paratypes are deposited in the helminthological collection of Instituto Oswaldo Cruz (CHIOC).

\section{RESULTS}

Mymarothecium boegeri $\mathrm{sp} . \mathrm{n}$.

Figs. 1-5

Description. Dactylogyridae, Ancyrocephalinae. Body 190-330 (275) (n=13) long by 70-95 (81) $(\mathrm{n}=$ 13) wide at level of ovary. Tegument smooth or presenting scaled annulations. Cephalic lobes developed. Two pairs of eyes; posterior pair larger and separated from anterior pair. Pharynx spherical to ovate, $20-25 \times 18-25$ $(21 \times 21)(\mathrm{n}=11)$. Peduncle broad; haptor, 35-75 (53) $(\mathrm{n}=6) \times 55-112(85)(\mathrm{n}=6)$. Anchors similar; ventral anchor 30-37 (32) $(n=5)$ long, dorsal anchor 27-37 (32) $(n=5)$ long; each having well-developed superficial root with slight depressions, deep root comparatively smaller, curved shaft, elongate point. Ventral bar V-shaped, 50-92 (63) ( $\mathrm{n}=10)$ long, with short posteromedial process. Dorsal bar broadly U-shaped, 40-52 (45) $(n=9)$ long. Haptor with 7 pairs of hooks with ancyrocephaline distribution. Pairs 1 and 6, 17-21 long; pairs 3, 4 and 7, 21-24 long; pair 2, 15-18 long; 

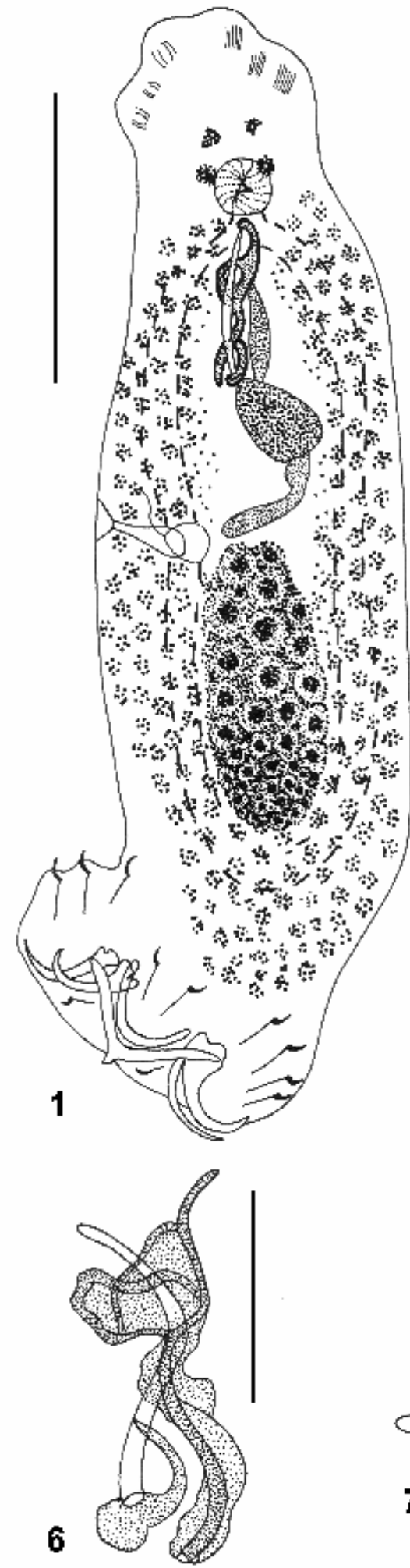
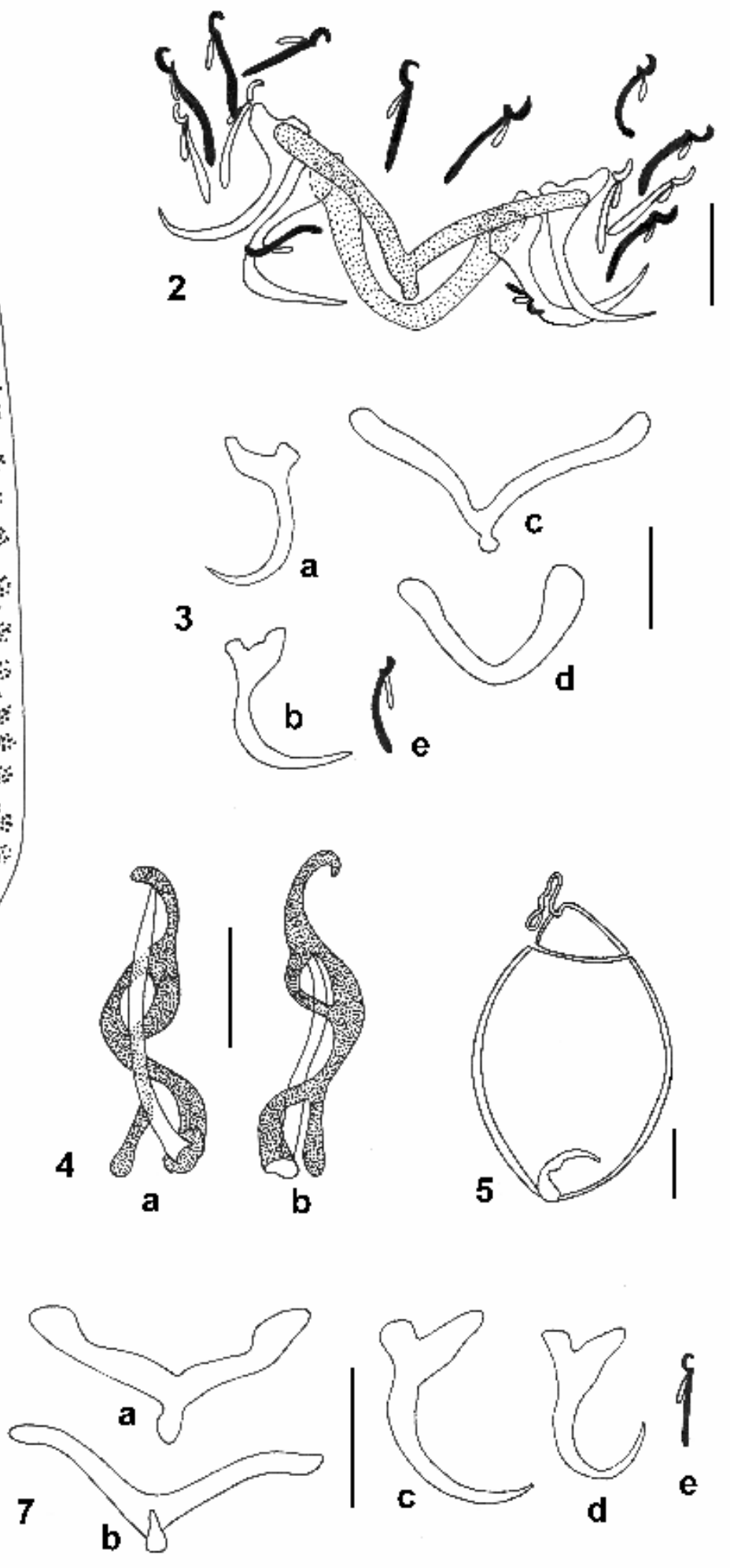

Figs. 1-5. Mymarothecium boegeri sp. n. Fig. 1. Total. Fig. 2. Haptoral sclerites. Fig. 3. a - ventral anchor; b - dorsal anchor; c ventral bar; d - dorsal bar; e - hook. Fig. 4. Copulatory complex: a -ventral; b - dorsal. Fig. 5. Egg. Figs. 6, 7. Mymarothecium viatorum Boeger, Piasecki et Sobecka, 2002. Fig. 6. Copulatory complex. Fig. 7. a - ventral bar; b - dorsal bar; c - ventral anchor; $\mathrm{d}$-dorsal anchor; $\mathrm{e}-$ hook. Scale bars: Fig. $1=10 \mu \mathrm{m}$; Figs. $2-5=20 \mu \mathrm{m}$; Figs. $6,7=30 \mu \mathrm{m}$. 
Table 1. Comparative measurements of Mymarothecium viatorum (range with mean in $\mu$ m, number of specimens measured).

\begin{tabular}{|l|c|c|c|}
\hline Host species & $\begin{array}{c}\text { Piaractus brachypomus } \\
\text { Buthority }\end{array}$ & $\begin{array}{c}\text { Piaractus brachypomus } \\
\text { Original measurements }\end{array}$ & $\begin{array}{c}\text { Piaractus mesopotamicus } \\
\text { Original measurements }\end{array}$ \\
\hline Locality & Poland & Brazil & Brazil \\
Length & $382-518(431) 12$ & $320-550(389) 5$ & $300-561(387) 22$ \\
Width & $69-89(78) 13$ & $80-180(126) 6$ & $79-188(125) 22$ \\
Pharynx & $18-25(22) 9$ & $16-25(20) 3 \times 19-26(22) 3$ & $16-27(21) 11 \times 19-26(22) 11$ \\
Ventral bar & $42-717$ & $45-75(62) 12$ & $50-71(61) 7$ \\
Median projection & - & $10-15(12) 3$ & $10-12(11) 3$ \\
Dorsal bar & $42-64(48) 6$ & $40-62(51) 10$ & $45-57(51) 6$ \\
Ventral anchor & $32-40(37) 6$ & $32-45(38) 25$ & $28-43(34) 11$ \\
Base width & $19-24(21) 6$ & - & $16-21(19) 3$ \\
Dorsal anchor & $35-40(36) 4$ & $30-40(34) 18$ & $30-41(35) 11$ \\
Hooks & & & \\
pair 1 & $18-26(21) 19$ & $17-25(21) 12$ & $13-20(17) 7$ \\
pair 2 & $18-26(21) 19$ & $19-24(17) 8$ & $16-21(18) 8$ \\
pair 3 & $18-26(21) 19$ & $20-30(25) 7$ & $19-28(21) 8$ \\
pair 4 & $18-26(21) 19$ & $25-31(28) 8$ & $23-30(27) 8$ \\
pair 5 & $17-19(18) 3$ & $12-17(14) 6$ & $11-17(14) 7$ \\
pair 6 & $18-26(21) 19$ & $19-24(22) 3$ & $17-24(20) 8$ \\
pair 7 & $18-26(21) 19$ & $21-24(22) 4$ & $15-20(18) 7$ \\
Egg & - & $97 \times 72$ & - \\
\hline
\end{tabular}

pair 5, 14-15 long. Each hook with delicate point, protruding thumb, shank comprising 2 subunits; filamentous hooklet (FH) loop extending to union of shank subunits. Copulatory organ comprising a narrow tube 36-48 (40) $(\mathrm{n}=8)$. Accessory piece bifurcated at base, with sinuous distal rod 34-55 (49) $(n=5)$, ring-shaped sub-terminal flap and hook-shaped process. Testis subovate, $10-20 \times 14-25(16 \times 21)(\mathrm{n}=7)$, seminal vesicle elongate; germarium elongate, 50-55 long. Vaginal aperture dextroventral. Vitelline follicles in two bilateral fields of trunk, extending from pharynx to level of haptor. Oviduct, ootype and uterus not observed.

Egg $85 \times 52$ with polar filaments; anterior filament coiled, 65 long, thinner than posterior filament; posterior filament 30 long.

$\mathrm{T}$ y p e h o s t : Colossoma macropomum (Cuvier, 1818) (Characidae).

T y p e lo c a lity: Aquaria of the "Centro de Pesquisas em Aquicultura Rodolfo von Ihering, DNOCS", Pentecoste City, State of Ceará, Brazil.

S i t e : Gills.

Prevale n c e: 6 of 21 fish infected.

$\mathrm{S} p$ e c i m e n s de p os it e d: CHIOC no. 36.453 (holotype) and nos. 36.454-36.457 (paratypes).

E t y m o lo g y: The specific name is in honour of Dr. Walter A. Boeger, in recognition of his contribution to knowledge of Monogenea.

Mymarothecium viatorum Boeger, Piasecki et Sobecka, 2002 Figs. 6-7, Table 1

Morphology and measurements (Table 1) of the specimens from both hosts are in agreement with the original description, with few differences. In the original description, the tegument was described as smooth, but scaled annulations occurred on body surface in some specimens of the present material.

Mymarothecium viatorum is characterized by having a posteromedial projection on the bars, differing from the other species of the genus, which have an anteromedial process on the ventral bar. The specimens studied herein showed different aspects of the posteromedial process of the ventral bar, depending on the state of contraction of the body, and were sometimes difficult to observe. After Boeger et al. (2002), the measurements of the 5th hooklet pair ranged from 17 to $19 \mu \mathrm{m}$ long but in our specimens, this pair showed a variation from 11 to $17 \mu \mathrm{m}$ long. The structure of the copulatory complex agreed with the original description.

H o s t s : Piaractus brachypomus (Cuvier, 1818) and Piaractus mesopotamicus (Holmberg, 1887) (Characidae) (new host record).

L o c a 1 i t y : Aquaria of DNOCS, Pentecoste City, State of Ceará, Brazil.

Material deposited: CHIOC nos. 36.458-36.460.

\section{DISCUSSION}

Mymarothecium Kritsky, Boeger et Jegu, 1996 was erected for four new species, Mymarothecium dactylotum, M. galeolum, M. perplanum, and M. whittingtoni. The genus characters included an anteromedial projection on the ventral bar, a non-sclerotized vagina that opens on the middorsal, dextrodorsal or dextroventral surfaces, and a non-coiled copulatory complex (Kritsky et al. 1996). Boeger et al. (2002) emended this diagnosis and allocated to this genus $M$. viatorum Boeger, Piasecki et Sobecka, 2002 that has a posteromedial process on the ventral bar. Mymarothecium boegeri conforms to the emended generic diagnosis. It is most simi- 
lar to $M$. whittingtoni and $M$. viatorum, considering the position of vaginal opening. It differs from $M$. viatorum in the absence of a projection on the dorsal bar and from $M$. whittingtoni in the posteromedial projection on ventral bar (anteromedial in $M$. whittingtoni). The new species differs from all other species of Mymarothecium in the characteristic structure of the copulatory organ.

Mymarothecium viatorum was described from Piaractus brachypomus in a warm-water canal of the Pomorzany power plant by the Odra River in Poland, representing the first record from a serrasalmid in Central Europe, outside of an aquarium. This species bears a posteromedial projection on the ventral bar.
In the present study, $M$. viatorum was collected from the gills of $P$. brachypomus and $P$. mesopotamicus from the aquaria of the Centre of Researches of DNOCS, in Brazil, confirming the occurrence of this species on its type host and a related host in the Neotropical Region of South America.

Acknowledgements. The authors are grateful to Dr. Marcelo Feitosa and "Centro de Pesquisas em Aquicultura Rodolfo von Ihering, Departamento Nacional de Obras contra as Secas", Pentecoste City, State of Ceará for the facilities offered during our stay and to Heloisa Maria N. Diniz, Laboratory for the Production and Handling of Images of Instituto Oswaldo Cruz, for assisting with preparation of figures.

\section{REFERENCES}

BOEGER W.A., PIASECKI W., SOBECKA E. 2002: Neotropical Monogenoidea. 44. Mymarothecium viatorum sp. n. (Ancyrocephalinae) from the gills of Piaractus brachypomus (Serrasalmidae, Teleostei) captured in a warm-water canal of a power plant in Szczecin, Poland. Acta Ichthyol. Pisc. 32: 157-162.

KRITSKY D.C., BOEGER W.A., JEGU M. 1996: Neotropical Monogenoidea. 28. Ancyrocephalinae (Dactylogyri- dae) of Piranha and their relatives (Teleostei, Serrasalmidae) from Brazil and French Guiana: species of Notozothecium Boeger and Kritsky, 1988 and Mymarothecium gen. n. J. Helminthol. Soc. Wash. 63: 153-175.

MIZELLE J.D. 1936: New species of trematodes from the gills of Illinois fishes. Am. Midl. Nat. 17: 785-806. 